\title{
The Volatility of Market Risk In Viet Nam Listed Banking, Insurance and Financial Services Company Groups after the Financial Crisis 2009-2011
}

\author{
Dinh Tran Ngoc Huy \\ Banking University, HCMC, Viet Nam \\ International University of Japan, Niigata, Japan \\ E-mail:dtnhuy2010@gmail.com
}

Received 18 October 2013

Accepted 21 October 2013

\begin{abstract}
The Viet Nam economy, especially the stock exchange, has been influenced by the global crisis during and after the period 2007-2009. How much risk for a typical industry in an emerging market such as Viet Nam? For specific industries, such as banking, insurance, investment and security industries, the risk re-analysis and estimation for the listed firms in these industries become necessary, esp. after the crisis period 2009-2011. First of all, by using quantitative and analytical methods to estimate asset and equity beta of four (4) groups of 32 financial service listed companies in Viet Nam banking, insurance, investment and security industries with a proper traditional model, we found out that the beta values, in general, for most companies are acceptable, excluding a few cases. There are $81 \%$ of listed firms with lower risk, among total 32 firms, whose beta values lower than $(<) 1$. This number is higher than that during the crisis period 2007-2009 (just 69\%, see Exhibit).Secondly, through the comparison of beta values among four (4) above industries, we recognized there are still $19 \%$ of total listed firms in the above group companies with beta values higher than (>) 1and have stock returns fluctuating more than the market index. Finally, this paper generates some outcomes that could provide both internal and external investors, financial institutions, companies and government more evidence in establishing their policies in investments and in governance.
\end{abstract}

Keywords: equity beta, financial structure, financial crisis, risk, asset beta, financial service industry.

\section{Introduction}

Together with such profitability parameters as ROI, ROE, firm risk can be used as an investment parameter for investors before they make an investment on either developing or developed financial markets. Hence, we perform a market risk analysis based on asset and equity beta of total 32 listed companies in the category of banking, insurance, investment and security firms. This paper emphasizes on analyzing un-diversifiable risk in the above industry in one of emerging markets: Vietnam stock market during the financial crisis 2007-2009. After the previous published article on estimated beta for listed construction company groups, we will compare the estimated beta results of listed Viet Nam banking institutions to those in its comparative activities such as insurance, investment and security companies to make a comparative analysis and risk evaluation after financial crisis impacts. No research, so far, has been done on the same topic.

This paper is organized as follow. The research issues and literature review will be covered in next sessions 2 and 3, for a short summary. Then, methodology and conceptual theories are introduced in session 4 and 5 . Session 6 describes the data in empirical analysis. Session 7 presents empirical results and findings. Then, session 8 gives analysis of risk. Lastly, session 9 will conclude with some policy suggestions. This paper also provides readers with references, exhibits and relevant web sources.

\section{Research Issues}

We mention a couple of issues on the estimating of beta for banking, insurance, investment/financial service and stock investment companies in Viet Nam stock exchange as following:

Hypothesis/Issue 1: Among the four (4) companies groups, under the financial crisis impact and high inflation, the beta or risk level of listed companies in the stock investment group will relatively higher than those in the rest three (3) industries.

Hypothesis/Issue 2: Because Viet $\mathrm{Nam}$ is an emerging and immature financial market and the stock market still in the recovering stage, there will be a large disperse distribution in beta values estimated in these four (4) industries.

Hypothesis/Issue 3: With the above reasons, the mean of equity and asset beta values of these 4 listed group companies tend to impose a high risk level, i.e., beta should higher than $(>) 1$.

\section{Literature Review}

Fama, Eugene F., and French, Kenneth R., (2004) also indicated in the three factor model that "value" and "size" are significant components which can affect stock returns. As Luis E. Peirero (2010) pointed, the 
task of estimating cost of equity in emerging markets is more difficult because of problems such as collecting data in short periods. Grullon (2012) pointed, there is evidence that the positive relation between firm-level stock returns and firm-level return volatility is due to real options that firms possess. Then, Becker and Schmidt (2012) stated that the influence of past stock price movements on volatilities and correlations is essential for understanding diversification and contagion in financial markets. Joshi (2012) found the results which reveal that the Asian stock markets exhibit the persistence of volatility, mean reverting behavior and volatility clustering..

Next, Wang et all (2013) failed to find a significant relationship between volatility of volatility and the variance risk premium. Bekaert (2013) found out the variance premium predicts stock returns while the conditional stock market variance predicts economic activity and has a relatively higher predictive power for financial instability than does the variance premium. And Fernandez (2013) also stated that industry betas are very unstable.

\section{Conceptual theories}

\section{Determinants of Equity and Asset Beta}

In financial markets, systematic risk relates to the overall risk of the whole market, is affected by some factors such as: interest rate fluctuations or economic crisis, can not be avoided by diversification, and is measured by a financial metric, beta which is also called systemic risk.

When an investor decides to make an investment in a single company and in a specific stock market, he or she will think of how much risk of the investment. Or what is the beta value of the stock or investment? This research will answer that question.

Of course, risk involves 2 parts: systematic risk (beta) and unsystematic risk, which is business risk or financial risk or diversifiable risk in which investors can reduce it by diversification.

Another application of beta is that it is used in the Capital asset pricing model (CAPM) to value a firm before making an M\&A and for pricing assets.

One example to see the meaning of beta is that, if beta of a real estate firm equals to 1,5 , the risk of the firm will be 1,5 times higher than the entire market and the return from the investment into this firm might be high equivalently.

\section{Methodology}

We select the 2009-2011 period as it is the time highlighting impacts from the financial crisis. Therefore, we use the data from the stock exchange market in Viet Nam (HOSE and HNX) during these two (2) years to estimate systemic risk results.

Firstly, we use the market stock price of total 32 listed companies in the banking, insurance, investment and security industries in Viet Nam stock exchange market to calculate the variability in monthly stock price in the same period; secondly, we estimate the equity beta for these four (4) listed groups of companies and make a comparison. Thirdly, from the equity beta values of these listed companies, we perform a comparative analysis between equity and asset beta values of these 4 companies groups in Viet Nam. Finally, we use the results to suggest policy for both these enterprises, financial services institutions and relevant organizations.

The below table 1 gives us the number of banking and other financial service (insurance, investment and security) firms used in the research of estimating beta:

\section{General Data Analysis}

We analyze the data (Table 1) of a sample of total 32 firms in 4 categories of industries: banking, insurance, investment and security groups, and the mean of equity beta is valued at 0.648 while that of asset beta is about 0.347. These data are acceptable values during the crisis. Furthermore, the sample variance of asset beta is quite low (0.101) which is a good number, while that of equity beta is a little bit higher (0.181). This shows us that the effectiveness of using financial leverage has decreased the systemic risk for the whole industry.

However, the max and min values of beta are still somewhat large (Table 2). Max equity beta value is up to 2.025 that is a little bit high, compared to max asset

Table 1 - Descriptive data of listed firms in the research

\begin{tabular}{|l|l|l|l|l|l|}
\hline Market & $\begin{array}{l}\text { Listed Banking } \\
\text { companies (1) }\end{array}$ & $\begin{array}{l}\text { Listed Insurance } \\
\text { companies (2) }\end{array}$ & $\begin{array}{l}\text { Listed Investment } \\
\text { \&financial service } \\
\text { companies (3) }\end{array}$ & $\begin{array}{l}\text { Listed Stock } \\
\text { Investment } \\
\text { companies (3) }\end{array}$ & Note (4) \\
\hline $\begin{array}{l}\text { Viet } \\
\text { Nam }\end{array}$ & 6 & 4 & 7 & 4 & $\begin{array}{l}\text { Estimating by traditional } \\
\text { method }\end{array}$ \\
\cline { 2 - 6 } & 3 & 3 & 3 & 2 & $\begin{array}{l}\text { Estimating by comparative } \\
\text { method }\end{array}$ \\
\hline Total & $\mathbf{9}$ & $\mathbf{7}$ & $\mathbf{1 0}$ & $\mathbf{6}$ & Total firms in groups: 32 \\
\hline
\end{tabular}

(Note: The above data is at the December 12th, 2010, from Viet Nam stock exchange) 
beta value is just 1.493 that is acceptable (see table 2). Looking at Table 3, we can see there is $19 \%$, or 6 listed firms still have beta values larger than $(>) 1$, whereas there is $81 \%$ or 26 firms whose beta values lower than $(<) 1$ and higher than $(>) 0$.

Table 2 - Estimating beta results for Four (4) Viet Nam Listed Banking and Other Financial Service Companies Groups (as of Dec 2011) (source: Viet Nam stock exchange data)

\begin{tabular}{|l|c|c|c|}
\hline $\begin{array}{l}\text { Statistic } \\
\text { results }\end{array}$ & $\begin{array}{c}\text { Equity } \\
\text { beta }\end{array}$ & $\begin{array}{c}\text { Asset beta } \\
\text { (assume debt } \\
\text { beta = 0) }\end{array}$ & Difference \\
\hline MAX & 2.025 & 1.493 & 0.5318 \\
\hline MIN & 0.114 & 0.037 & 0.0764 \\
\hline MEAN & 0.648 & 0.347 & 0.3008 \\
\hline VAR & 0.1814 & 0.1011 & 0.0803 \\
\hline \multicolumn{4}{|c|}{ Note: Sample size : 32 } \\
\hline
\end{tabular}

Table 3 - The number of companies in research sample with different beta values and financial leverage

\begin{tabular}{|c|c|c|c|}
\hline $\begin{array}{c}\text { Equity } \\
\text { Beta }\end{array}$ & $\begin{array}{c}\text { No. of } \\
\text { firms }\end{array}$ & $\begin{array}{c}\text { Financial leverage } \\
\text { (average) }\end{array}$ & Ratio \\
\hline$<0$ & 0 & $0,00 \%$ & $0 \%$ \\
\hline $0<$ beta<1 & 26 & $51.32 \%$ & $81 \%$ \\
\hline Beta $>1$ & 6 & $58.32 \%$ & $19 \%$ \\
\hline total & 32 & $52.6 \%$ & $100 \%$ \\
\hline
\end{tabular}

\begin{tabular}{|c|c|c|c|}
\hline Asset Beta & $\begin{array}{c}\text { No. of } \\
\text { firms }\end{array}$ & $\begin{array}{c}\text { Financial leverage } \\
\text { (average) }\end{array}$ & Ratio \\
\hline$<0$ & 0 & $0,00 \%$ & $0 \%$ \\
\hline $0<$ beta $<1$ & 31 & $53.48 \%$ & $97 \%$ \\
\hline Beta $>1$ & 1 & $26.26 \%$ & $3 \%$ \\
\hline total & 32 & $0.7 \%$ & $100 \%$ \\
\hline
\end{tabular}

Value of equity beta varies in a range from 2.025 (max) to $-1.592(\min )$ and that of asset beta varies in a range from 1.478 (max) to 0.114 (min). Some companies still has larger risk exposure than most of the others. There are no listed companies whose betas are lower than $(<) 0$, which means no firms has the stock return moving in an opposite direction to the market index.

Next, Asset beta max value is 1.493 and min value is 0.037 which show us that if beta of debt is assumed to be zero (0), the company's financial leverage contributes to a decrease in the market risk level.

Lastly, we can see the relatively high difference between max equity and max asset beta values, which is about 0.532, whereas there is a smaller difference between equity and asset beta variance values which is just 0.076; so, there is certain impact on systemic risk of certain firms in term of using leverage while it indicates for most of firms that financial leverage can enable them to reduce market risk. And there is not quite big effect from financial leverage on the gap between company's beta variance values.

\section{Empirical Research Findings and Discussion}

A-Banking listed companies group

After the crisis 2007-2009, the market for these institutions still exists and grows, but has certain difficulties. The rising inflation and rising lending interest rates and higher opportunity costs made input materials or production costs increasing. So, the market for borrowing firms has been affected because selling prices increase.

Table 4 below shows us the research of 9 listed firms in this category during the above period. In general, the mean of equity beta and asset beta are 0.492 and 0.130 , accordingly. These values are good numbers in term of indicating a low and acceptable un-diversifiable risk. The market demand for financial services is still high.

Besides, the variance of equity and asset beta of the sample group equals to $\mathbf{0 . 0 7 3}$ and $\mathbf{0 . 0 0 5}$ accordingly which are lower than the variance of the entire sample equity and asset beta of $\mathbf{0 . 1 8 1}$ and $\mathbf{0 . 1 0 1}$. The effect from financial leverage makes these beta values fluctuate a little bit less than the sample beta mean.

We might note that equity beta values of 9 firms in this material category are a little lower than those of firms in the rest two (2) groups: finance and stock investment, but higher than that of insurance firms. This might be considered as one characteristic of these industries. Among four (4) industries, the systemic risk of banking group companies is a bit higher than that of insurance group.

Besides, the estimated equity beta mean is $\mathbf{0 . 4 9 2}$ and sample variance is $\mathbf{0 . 1 3 0}$, which is not supporting our $2^{\text {nd }}$ research hypothesis or issue that there would be a large disperse distribution in beta values estimated in this industry as well as our $3^{\text {rd }}$ research hypothesis or issue that the mean of equity and asset beta values of these listed companies tend to impose a high risk level or beta should higher than (>) 1. (see Table 5).

\section{B- Insurance listed companies group}

In an emerging market such as Viet Nam, the market for insurance firms is definitely potential because of the public need for such necessary vital products and though it may be affected by impacts from the financial crisis.

Table 6 below shows us the equity and asset beta mean of 7 listed insurance companies, with values of 0.469 and 0.214 , accordingly. This result, which means the risk is low and negative because there are only one among 7 firms with beta $>0$. We note that equity and asset beta var have acceptable values of 0.162 and 
Table 4 - Estimating beta results for Viet Nam Listed Banking Companies (as of Dec 2011)

(source: Viet Nam stock exchange data)

\begin{tabular}{|c|c|c|c|c|c|}
\hline $\begin{array}{l}\text { Order } \\
\text { No. }\end{array}$ & $\begin{array}{l}\text { Company } \\
\text { stock code }\end{array}$ & $\begin{array}{l}\text { Equity } \\
\text { beta }\end{array}$ & $\begin{array}{l}\text { Asset beta (assume } \\
\text { debt beta }=0 \text { ) }\end{array}$ & Note & $\begin{array}{l}\text { Financial leverage } \\
\text { (F.S reports) }\end{array}$ \\
\hline 1 & $\mathrm{ACB}$ & 0.636 & 0.152 & & $95.2 \%$ \\
\hline 2 & CTG & 0.554 & 0.136 & & $94.4 \%$ \\
\hline 3 & EIB & 0.385 & 0.106 & & $90.5 \%$ \\
\hline 4 & $\mathrm{HBB}$ & 0.346 & 0.098 & $\begin{array}{l}\text { SHB as } \\
\text { comparable }\end{array}$ & $89.7 \%$ \\
\hline 5 & MBB & 0.234 & 0.061 & $\begin{array}{l}\text { STB as } \\
\text { comparable }\end{array}$ & $92.5 \%$ \\
\hline 6 & NVB & 0.125 & 0.037 & $\begin{array}{l}\text { HBB as } \\
\text { comparable }\end{array}$ & $87.7 \%$ \\
\hline 7 & SHB & 1.004 & 0.267 & & $91.8 \%$ \\
\hline 8 & STB & 0.734 & 0.204 & & $90.3 \%$ \\
\hline \multirow[t]{2}{*}{9} & VCB & 0.408 & 0.106 & & $92.7 \%$ \\
\hline & & & & Average & $91.6 \%$ \\
\hline
\end{tabular}

0.046. This indicates the good effect from using financial leverage.

Table 5 - Statistical results for Vietnam listed Banking companies

\begin{tabular}{|l|c|c|c|}
\hline $\begin{array}{l}\text { Statistic } \\
\text { results }\end{array}$ & $\begin{array}{c}\text { Equity } \\
\text { beta }\end{array}$ & $\begin{array}{c}\text { Asset beta } \\
\text { (assume debt } \\
\text { beta = 0) }\end{array}$ & Difference \\
\hline MAX & 1.004 & 0.267 & 0.7371 \\
\hline MIN & 0.125 & 0.037 & 0.0878 \\
\hline MEAN & 0.492 & 0.130 & 0.3623 \\
\hline VAR & 0.0733 & 0.0050 & 0.0682 \\
\hline \multicolumn{4}{|c|}{ Note: Sample size : 9} \\
\hline
\end{tabular}

The Table 6 below shows us the equity and asset beta mean of 7 listed insurance companies, with values of 0.469 and 0.214 , accordingly. This result, which means the risk is low and negative because there are only one among 7 firms with beta $>0$. We note that equity and asset beta var have acceptable values of 0.162 and 0.046. This indicates the good effect from using financial leverage.

Beside, this is the group with the lowest equity beta mean.

Table 6 - Estimating beta results for Viet Nam Listed Insurance Companies (as of Dec 2011) (source: Viet Nam stock exchange data)

\begin{tabular}{|c|c|c|c|c|c|}
\hline Order No. & $\begin{array}{l}\text { Company stock } \\
\text { code }\end{array}$ & Equity beta & $\begin{array}{l}\text { Asset beta (assume } \\
\text { debt beta }=0 \text { ) }\end{array}$ & Note & $\begin{array}{l}\text { Financial } \\
\text { leverage }\end{array}$ \\
\hline 1 & $\mathrm{BVH}$ & 0.966 & 0.252 & & $73.9 \%$ \\
\hline 2 & $\mathrm{PVI}$ & 0.558 & 0.345 & & $38.1 \%$ \\
\hline 3 & $A B I$ & 0.288 & 0.104 & & $63.8 \%$ \\
\hline 4 & $\mathrm{BIC}$ & 0.114 & 0.037 & $\begin{array}{l}\mathrm{ABI} \text { as } \\
\text { comparable }\end{array}$ & $67.3 \%$ \\
\hline 5 & BMI & 1.063 & 0.627 & & $41.0 \%$ \\
\hline 6 & PGI & 0.150 & 0.067 & $\begin{array}{l}\mathrm{ABI} \text { as } \\
\text { comparable }\end{array}$ & $55.2 \%$ \\
\hline \multirow[t]{2}{*}{7} & PTI & 0.145 & 0.063 & $\begin{array}{l}\mathrm{ABI} \text { as } \\
\text { comparable }\end{array}$ & $56.7 \%$ \\
\hline & & & & Average & $56.6 \%$ \\
\hline
\end{tabular}

Published by Atlantis Press

Copyright: the authors 
Table 7 - Statistical results for Vietnam listed Insurance companies

\begin{tabular}{|l|c|c|c|}
\hline Statistic results & Equity beta & Asset beta (assume debt beta = 0) & Difference \\
\hline MAX & 1.063 & 0.627 & 0.4354 \\
\hline MIN & 0.114 & 0.037 & 0.0764 \\
\hline MEAN & 0.469 & 0.214 & 0.2554 \\
\hline VAR & 0.1622 & 0.0462 & 0.1160 \\
\hline \multicolumn{4}{|c|}{ Note: Sample size : 7 } \\
\hline
\end{tabular}

Table 8 - Estimating beta results for Viet Nam Listed Investment \& Financial service Companies (as of Dec 2011) (source: Viet Nam stock exchange data)

\begin{tabular}{|c|c|c|c|c|c|}
\hline $\begin{array}{l}\text { Order } \\
\text { No. }\end{array}$ & $\begin{array}{l}\text { Company } \\
\text { stock code }\end{array}$ & $\begin{array}{l}\text { Equity } \\
\text { beta }\end{array}$ & $\begin{array}{l}\text { Asset beta (assume } \\
\text { debt beta }=0 \text { ) }\end{array}$ & Note & $\begin{array}{l}\text { Financial } \\
\text { leverage }\end{array}$ \\
\hline 1 & AGR & 1.370 & 0.313 & & $77.2 \%$ \\
\hline 2 & APG & 0.648 & 0.630 & CLS as comparable & $2.8 \%$ \\
\hline 3 & APS & 0.895 & 0.382 & & $57.4 \%$ \\
\hline 4 & AVS & 0.546 & 0.425 & CLS as comparable & $22.1 \%$ \\
\hline 5 & $\mathrm{BSI}$ & 1.125 & 0.873 & AGR as comparable & $22.4 \%$ \\
\hline 6 & BVS & 2.025 & 1.493 & & $26.3 \%$ \\
\hline 7 & CLS & 0.662 & 0.331 & & $50.0 \%$ \\
\hline 8 & CTS & 0.812 & 0.546 & & $32.8 \%$ \\
\hline 9 & PVF & 1.334 & 0.116 & & $91.3 \%$ \\
\hline 10 & VNR & 0.230 & 0.131 & & $43.0 \%$ \\
\hline
\end{tabular}

Table 9 - Statistical results for Vietnam listed Investment \& Financial service companies

\begin{tabular}{|l|c|c|c|}
\hline $\begin{array}{l}\text { Statistic } \\
\text { results }\end{array}$ & Equity beta & $\begin{array}{c}\text { Asset beta (assume } \\
\text { debt beta = 0) }\end{array}$ & Difference \\
\hline MAX & 2.025 & 1.493 & 0.5318 \\
\hline MIN & 0.230 & 0.116 & 0.1135 \\
\hline MEAN & 0.965 & 0.524 & 0.4407 \\
\hline VAR & 0.2650 & 0.1672 & 0.0978 \\
\hline \multicolumn{4}{|c|}{ Note: Sample size : 10} \\
\hline
\end{tabular}

\section{D- Stock investment listed companies group}

Many firms in this category have difficulties in their operation during these years. Different from firms in the other three (3) industries, 6 listed stock investment firms has the lowest value of equity beta var of 0.0375 and the $2^{\text {nd }}$ lowest value of asset beta var of 0.048 , showing market risk with less dispersion.

Max beta values of 0.76 and 0.756 are the low and acceptable values with the small difference of beta means of 0.028 . This indicates a less impact from using leverage in level of market risks among firms in this industry (compared to 0.440 in the investment and finance group).

The asset beta mean value is 0.533 (the highest) and equity beta mean value is 0.561 (the $2^{\text {nd }}$ highest in 4 groups) shows the financial leverage has less impacts on market risk exposure in this category during the crisis period, compared to the other industries.

Please refer to Table 10 and Table 11 for more information.

Table 10 - Estimating beta results for Viet Nam Listed Stock Investment Companies (as of Dec 2011) (source: Viet Nam stock exchange data)

\begin{tabular}{|r|l|r|r|l|r|}
\hline $\begin{array}{l}\text { Order } \\
\text { No. }\end{array}$ & $\begin{array}{l}\text { Company } \\
\text { stock code }\end{array}$ & Equity beta & $\begin{array}{l}\text { Asset beta (assume } \\
\text { debt beta = 0) }\end{array}$ & Note & $\begin{array}{l}\text { Financial } \\
\text { leverage }\end{array}$ \\
\hline 1 & ASIAGF & 0.419 & 0.274 & MAFPF1 as comparable & $34.6 \%$ \\
\hline 2 & MAFPF1 & 0.586 & 0.583 & & $0.4 \%$ \\
\hline 3 & PRUBF1 & 0.265 & 0.264 & & $0.3 \%$ \\
\hline 4 & VFMVF1 & 0.760 & 0.751 & & $1.2 \%$ \\
\hline 5 & VFMVF4 & 0.758 & 0.756 & & $0.4 \%$ \\
\hline 6 & VFMVFA & 0.580 & 0.572 & MAFPF1 as comparable & $1.4 \%$ \\
\hline
\end{tabular}


Table 11 - Statistical results for Vietnam listed Stock Investment companies

\begin{tabular}{|l|c|c|c|}
\hline $\begin{array}{l}\text { Statistic } \\
\text { results }\end{array}$ & $\begin{array}{c}\text { Equity } \\
\text { beta }\end{array}$ & $\begin{array}{c}\text { Asset beta (assume } \\
\text { debt beta = 0) }\end{array}$ & Difference \\
\hline MAX & 0.760 & 0.756 & 0.0050 \\
\hline MIN & 0.265 & 0.264 & 0.0009 \\
\hline MEAN & 0.561 & 0.533 & 0.0281 \\
\hline VAR & 0.0375 & 0.0481 & -0.0106 \\
\hline \multicolumn{4}{|c|}{ Note: Sample size : 6} \\
\hline
\end{tabular}

\section{E-Comparison among 4 groups of banking and other financial service companies}

In the below charts (Figure 1, Figure 2 and Figure 3), we can see among the 4 groups, equity beta values of the banking and insurance groups are the lowest $(0.49$ and 0.47$)$ and asset beta values of these groups are also the lowest $(0.13$ and 0.21$)$, while equity beta mean of investment and finance group is the highest (0.96) and asset beta mean of the stock investment is the highest (0.53). Assuming debt beta is 0 , financial leverage has helped many listed firms in these industries lower the un-diversifiable risk.

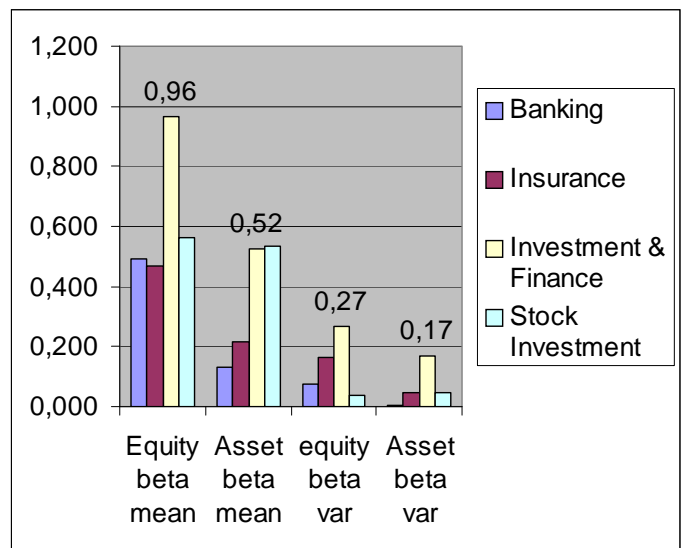

Figure 1 - Statistical results of four (4) groups of 32 listed VN banking and other financial service firms after the crisis period 2009-2011

Additionally, we could see the asset beta mean values of all 4 groups are not big and lower than $(<0.6)$ and acceptable. Therefore, it also rejects our $3^{\text {rd }}$ hypothesis that the mean values of equity/asset beta of all 4 groups impose higher risks.

Next, we can recognize from the chart that, the risk in the stock investment industry higher than those in the other industries. So, it supports our $1^{\text {st }}$ hypothesis.

Last but not least, from the calculated results, variance of asset beta in the financial service industries are low (vary in range of 0.01 to 0.17 ). This also rejects our $2^{\text {nd }}$ hypothesis.

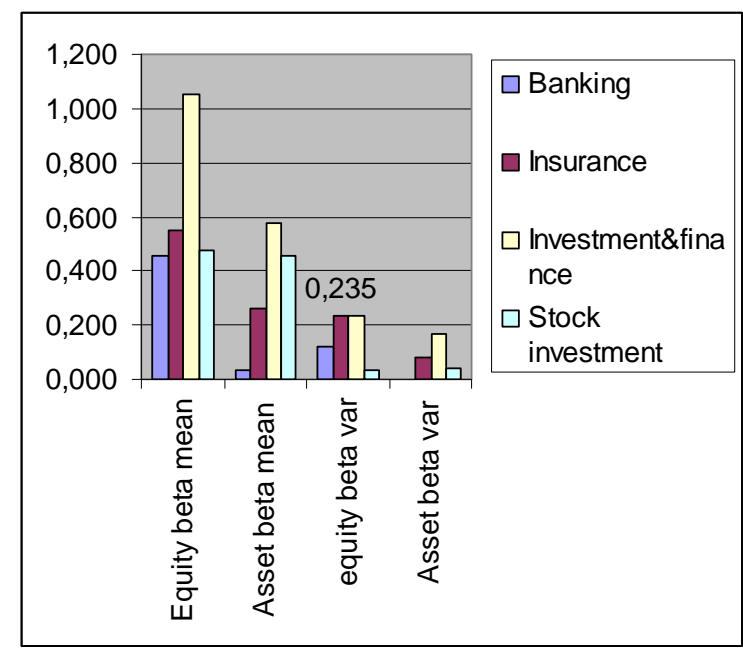

Figure 2 - Statistical results of four (4) groups of 32 listed VN banking and other financial service firms during/after the crisis period 2007-2011.

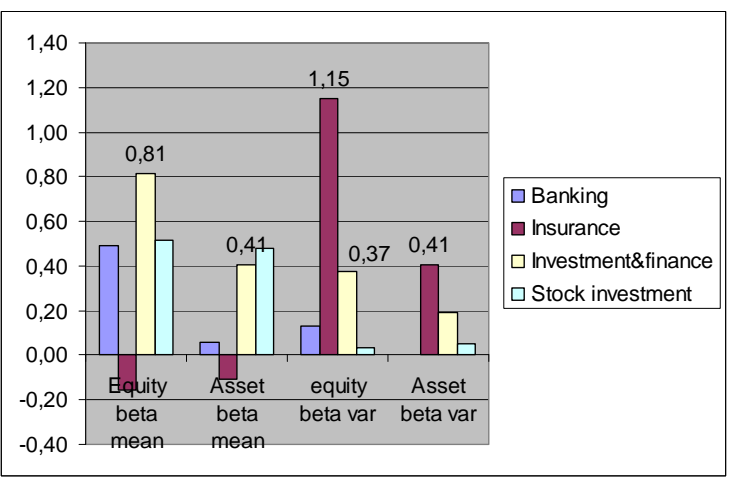

Figure 3 - Statistical results of four (4) groups of 32 listed VN banking and other financial service firms during/after the crisis period 2007-2009

\section{Risk Analysis}

Generally, the financial crisis will affect the whole economy and slowdown the speed of ODA and FDI capital invested into financial service industries in Viet Nam. Additionally, it has some negative impacts on Viet Nam stock market which is in the down turn. And it also might have indirect impacts on banking industry through macro factors such as interest rates, exchange rates. From financial service industry and banking industry, the level of crisis impacts can move to other markets such as real estate market.

However, there are positive efforts from market participants. For example, banks and insurance firms have created many more joint products and services. This enables companies to enhance their brand names. 


\section{Conclusion and Policy suggestion A-Banking industry}

This is the group with the $2^{\text {nd }}$ highest number of listed companies (9 firms). In is noted that beta mean values are fine ( 0.49 and 0.13 accordingly), and this is the industry which has both the $2^{\text {nd }}$ lowest asset beta mean value and the lowest asset beta var (0.13 and 0.01) (see figure 1). During the crisis, this industry has lower market risk and beta values of firms in the group are less fluctuated.

After increasing rates period, financial services industries, the government and central banks have certain efforts and proper policies to support businesses and internal investors, and stabilize inflation.

\section{B-Insurance industry}

Generally speaking, this is the industry which has the lowest value of equity bet mean, among 4 groups (0.47) and the $2^{\text {nd }}$ lowest value of asset beta var (0.046). All 7 firms have beta values lower than $(<) 1$ and there are one firm whose beta value is higher than $(>) 0$. The market is established and data is acceptable for the period 2009-2011. Furthermore, the risk dispersion decreases from 1.15 during the period 2007-2009 (see figure 3) to 0.17 during the period 2009-2011 and 0.24 for the whole period 2007-2011 (see figure 2).

\section{C-Investment \& Financial service industry}

Through our comparative analysis on asset beta values, this is the industry which has the highest number of firms (10 firms) and which has the highest equity beta mean and the $2^{\text {nd }}$ highest asset beta mean ( 0.96 and 0.52 accordingly), as well as the highest values of equity and asset beta var (0.27 and 0.17). But it has lower asset beta mean than that of the stock investment industry.

\section{D-Stock investment industry}

In our comparative analysis on asset beta values, this is the industry which has the smallest number of companies (6 firms) and which has the lowest values of equity beta var of 0.037 and the $2^{\text {nd }}$ lowest asset beta var of 0.05 . This shows us the lower level of dispersion of market risk compared to other industries although the leverage tends to expand the risk exposure. On the other hand, asset beta mean value of 0.533 ranks the highest and equity beta mean of 0.56 ranks the $2^{\text {nd }}$ highest among 4 groups. When we consider impacts of financial leverage, market risk exposure and dispersion is lower than that of the other three (3) industries. But the leverage has more effects on the investment and financial service industry when we note the equity/asset beta mean values of these 2 groups.
In general, our empirical findings state that they are not in favor of our $2^{\text {nd }}$ and $3^{\text {rd }}$ hypotheses or research issues but support our $1^{\text {st }}$ hypothesis.

In short, though Viet Nam is an emerging market with growing financial system, the equity beta values estimated are at acceptable level with $81 \%$ firms in the research sample while just a few companies' beta values are risky (about 19\% firms). In term of asset beta values, there are $97 \%$ of firms whose beta in a range 0 1 , and only $3 \%$ or 1 firm whose beta $>1$.

Additionally, it indicates the higher the using of financial leverage, the lower the beta values. In reality, there are $81 \%$ of financial service firms (26 among 32 firms) which has $0<$ beta $<1$ in this research sample. If used effectively, using leverage can be good for risk management.

Furthermore, if we compare these data and values to those of construction and real estate firms, and to those of computer and electrical companies in our previous research (see exhibit 4 and 5), for the crisis period 20072009, we might see that in here, the equity beta mean of investment and finance groups can be a little bit higher than those of computer and electrical firms but those of banking and insurance could be lower, whereas asset beta mean of these firms are lower than those of construction and real estate firms and while the impacts from the crisis happens on the overall market. So, the leverage becomes more meaningful and the crisis might have less influence on the firms in the above research.

Last but not least, looking at figure 1 and 3 , it is noted that both equity and asset beta mean values of the insurance firms varied from negative to positive and have the same movement direction with the market.

Finally, this paper suggests implications for further research and policy suggestion for the Viet Nam government and relevant organizations, economists and investors from current market conditions.

\section{Acknowledgements}

My sincere thanks are for the editorial office and Lecturers/Doctors at Banking University, HCMC, Viet Nam and at International University of Japan, Niigata, Japan and Arhus business school, Denmark, as well as Amos Tuck school of business, USA. Through the qualitative analysis, please kindly email me if any error found

\section{References}

1. Becker, C., and Schmidt, W.M., (2012), Volatility, Correlation, and the Market Trend, SSRN Working Paper

2. Bekaert, G., and Hoerova, M., (2013), The VIX, The Variance Premium and Stock Market 
Dinh Tran Ngoc Huy

Volatility, Columbia Business School Research Paper No. 13-32

3. Eugene, Fama F., and French, Kenneth R., (2004), The Capital Asset Pricing Model: Theory and Evidence, Journal of Economic Perspectives

4. Eugene, Fama F., and French, Kenneth R., (2006), The Value Premium and the CAPM, Journal of Finance

5. Fernandez, Pablo., (2008), Levered and Unlevered Beta, SSRN Working paper series

6. Grullon, G., Lyandres, E., and Zhdanov, A., (2012), Real Options, Volatility, and Stock Returns, Journal of Finance

7. Huy, Dinh T.N., (2012), Estimating Beta of Viet Nam listed construction companies groups during the crisis, Journal of Integration and Development

8. Joshi, P., (2012), Financial Crisis and Volatility Behaviour of Stock Markets of Asia, QuestJournal of Management and Research

9. Pereiro, Luis E.,(2010), The Beta Dilemma in Emerging Markets, Journal of Applied Corporate Finance

10. Wang, R., Kirby, C., and Clark, S.P., (2013), Volatility of Volatility, Expected Stock Return and Variance Risk Premium, SSRN Working Paper

11. http://www.mofa.gov.vn/vi/

12. http://www.hsx.vn/hsx/ 